\title{
Importance of the interferon- $\alpha$ system in murine large intestine indicated by microarray analysis of commensal bacteria-induced immunological changes
}

\author{
Kaori Munakata ${ }^{\dagger 1}$, Masahiro Yamamoto ${ }^{\dagger 1,2}$, Naoko Anjiki3, \\ Mitsue Nishiyama ${ }^{2}$, Sachiko Imamura ${ }^{2}$, Seiichi Iizuka ${ }^{2}$, Kiyoe Takashima1, \\ Atsushi Ishige $^{1}$, Kyoji Hioki ${ }^{4}$, Yasuyuki Ohnishi ${ }^{4}$ and Kenji Watanabe*1
}

Address: ${ }^{1}$ Center for Kampo Medicine, School of Medicine, Keio University, 35 Shinano-machi, Shinjuku-ku, Tokyo 160-8582, Japan, ${ }^{2}$ Pharmacology Research Department, Tsumura Central Research Laboratories, Tsumura \& Co., 3586 Yoshiwara, Ami-machi, Inashiki-gun, Ibaraki 300-1192, Japan, ${ }^{3}$ Graduate School of Natural Science and Technology, Kanazawa University, Kakuma-machi, Kanazawa 920-1192, Japan and ${ }^{4}$ Central Institute for Experimental Animals, 1430 Nogawa, Miyamae-ku, Kawasaki, Kanagawa 216-0001, Japan

Email: Kaori Munakata - di055014@sc.itc.keio.ac.jp; Masahiro Yamamoto - hirokoma@h.email.ne.jp; Naoko Anjiki - anjiki@nihs.go.jp; Mitsue Nishiyama - nishiyama_mitsue@mail.tsumura.co.jp; Sachiko Imamura - imamura_sachiko@mail.tsumura.co.jp; Seiichi Iizuka - iiduka_seiichi@mail.tsumura.co.jp; Kiyoe Takashima - takashima_kiyoe@yahoo.co.jp; Atsushi Ishige - ishige@sc.itc.keio.ac.jp; Kyoji Hioki - hioki@ciea.or.jp; Yasuyuki Ohnishi - kiyasho@ciea.or.jp; Kenji Watanabe* - toyokeio@sc.itc.keio.ac.jp

* Corresponding author †Equal contributors

Published: 26 April 2008

BMC Genomics 2008, 9:192 doi:10.1186/1471-2164-9-192
Received: 17 July 2007

Accepted: 26 April 2008

This article is available from: http://www.biomedcentral.com/I47I-2/64/9/192

(c) 2008 Munakata et al; licensee BioMed Central Ltd.

This is an Open Access article distributed under the terms of the Creative Commons Attribution License (http://creativecommons.org/licenses/by/2.0), which permits unrestricted use, distribution, and reproduction in any medium, provided the original work is properly cited.

\begin{abstract}
Background: Although microbiota play a critical role in the normal development and function of host immune systems, the underlying mechanisms, especially those involved in the large intestine (LI), remain unknown. In the present study, we performed transcriptome analysis of the LI of germfree (GF) and specific pathogen-free (SPF) mice of the IQI strain, an inbred strain established from ICR mice.
\end{abstract}

Results: GeneChip analysis, quantitative real-time RT-PCR, and reconfirmation using bacteriainoculated GF mice revealed differences in the expression levels of several immune-related genes, such as cryptdin-related sequences (CRS), certain subsets of type I interferon (IFN)-related genes, class Ib MHC molecules, and certain complements. LI expressed no authentic cryptdins but predominantly expressed CRS2, 4, and 7. The mRNA levels of IFN-related genes, including Irf7, Isgf3g, Ifit I and Stat I, were lower in SPF- and flora-reconstituted mice. When an oral IFN- $\alpha$ inducer tilorone analog, RI I567DA, was administered to SPF mice, IFN- $\alpha$ was induced rapidly in the LI at $4 \mathrm{~h}$, whereas no IFN- $\alpha$ protein was detected in the small intestine (SI) or blood. In situ hybridization and immunohistochemistry suggested that the IFN- $\alpha$ production originated from Paneth cells in the $\mathrm{SI}$, and portions of lamina proprial CDI Ib- or mPDCAI-positive cells in the LI.

Conclusion: The present study suggests that microbial colonization, while inducing the expression of anti-microbial peptides, results in the down-regulation of certain genes responsible for immune responses, especially for type I IFN synthesis. This may reflect the adaptation process of the immune system in the $\mathrm{LI}$ to prevent excessive inflammation with respect to continuous microbial exposure. Further, the repertoire of anti-microbial peptides and the extraordinary role of interferon producing cells in the LI have been found to be distinct from those in the SI. 


\section{Background}

Humans harbor an enormous number of microbes in the intestine. Intestinal flora have been suggested to play a critical role in the normal development and physiology of host animals. Symbiosis of human commensal bacteria forms a metasystem of nutrient uptake and endobiotic/ xenobiotic metabolism whose capacities greatly exceed those provided by the products of genes encoded in the human genome [1]. Further, gut microbiota are a key regulator of the human immune system. The immune response must be balanced between defending against pathogens while at the same time recognizing commensals as harmless [1-3]. The immune system of the small intestine, which is comprised of a variety of regulatory and effector compartments including Peyer's Patch cells, intraepithelial lymphocytes, lamina propria mononuclear cells and intestinal epithelial cells, has been extensively documented $[4,5]$. The normal colon, however, apparently lacks important structures/components such as Peyer's patches (PP) and Paneth cells, and little is known about the immunology of the large intestine, despite the marked differences in both function and luminal environment between the different regions of the intestine $[6,7]$.

Previous studies using germ-free (GF)-, bacteria-reconstituted GF-, specific pathogen-free (SPF)- and conventional $(\mathrm{CV})$ - mice have revealed that enteric bacteria have profound effects on the number and population of immune cells in PP $[4,8,9]$, differentiation of Paneth cells [10-12], migration of $\mathrm{T}$ cells bearing $\alpha / \beta \mathrm{T}$ cell receptor into the intestinal epithelium [13], development of IFN- $\gamma$-driven immune function $[14,15]$ such as Th1 skewing [16] and MHC class II antigen expression [17,18], and oral tolerance induction $[8,16,19]$. Although functional genomics have demonstrated that enteric bacteria affect the expression of genes involved in the mucosal barrier and immu- nological defense [20,21], the mechanisms by which these immunological changes are induced, especially in the large intestine, are still obscure.

In the present study, transcriptome analysis was performed on colon tissues from IQI mice, an inbred strain established from ICR mice [22]. IQI mice are an autoimmune-prone strain: they induce a high level of antinuclear auto-antibody following mercuric chloride treatment [23], have thymic B cells [24], show age-related development of Sjogren's syndrome-like sialadenitis [25], and exhibit spontaneous skin lesions in aged females [26]. Comparisons of picryl chloride-induced contact dermatitis in BALB/C and IQI mice suggested that enhanced antigen presentation capacity in the ear dermis of IQI mice resulted in prominent $\mathrm{T}$ cell infiltration and more severe dermatitis as compared with BALB/c mice [26,27]. High sensitivity in the mucosal sites in IQI mice suggests that this strain may be useful for investigating changes in mucosa-associated immune systems induced by bacterial burden. The present results demonstrated that bacterial colonization increases the expression of cryptdin-like products and decreases the expression of regulatory factors that are indispensable prerequisites for massive IFN$\alpha$ synthesis. Our investigation of the cells responsible for these changes by in situ hybridization and time course analysis of IFN- $\alpha$ production suggested that IFN- $\alpha$ plays an important role in the defense response in the large intestine.

\section{Results \\ GeneChip analysis of the large intestines of GF and SPF mice}

There were 11 probe sets whose expression levels in SPF mice were significantly ( $>2$ fold) higher than in GF mice (Table 1). Among these 11 probe sets, 6 were those of the

Table I: Genes more highly expressed in large intestines of SPF mice than those in GF mice

\begin{tabular}{|c|c|c|c|c|}
\hline Probe Set ID & Gene Name* & Gene Symbol & Fold Change** & $\mathrm{P}$-value \\
\hline 160918_at & SI00 calcium binding protein $\mathrm{G}$ & $\mathrm{SIO0} \mathrm{g}$ & 10.16 & 0.006 \\
\hline 10035I_f_at & defensin related cryptdin 3/defensin-related cryptdin 23 & Defcr3/Defcr23 & 5.27 & 0.049 \\
\hline 9955 I_f_at & defensin related cryptdin 5 & Defcr5 & 4.79 & 0.022 \\
\hline 93863_f_at & $\begin{array}{l}\text { defensin related cryptdin 3/defensin related cryptdin } 6 / \\
\text { defensin-related cryptdin 23/defensin-related cryptdin } 24\end{array}$ & $\begin{array}{l}\text { Defcr3/Defcr6/Defcr23/ } \\
\text { Defcr24 }\end{array}$ & 4.30 & 0.034 \\
\hline 93879_f_at & defensin related cryptdin 3 & Defcr3 & 4.00 & 0.031 \\
\hline $92812 \_f \_a t$ & $\begin{array}{l}\text { defensin related cryptdin 3/defensin related cryptdin } 4 / \\
\text { defensin related cryptdin 6/RIKEN cDNA } 2010016 \text { FI } 4 \text { gene/ } \\
\text { defensin-related cryptdin 23/defensin-related cryptdin } 24\end{array}$ & $\begin{array}{l}\text { Defcr3/Defcr4/Defcr6/ } \\
\text { 20I0016FI4Rik/Defcr23/ } \\
\text { Defcr24 }\end{array}$ & 3.67 & 0.018 \\
\hline 160909_at & small proline-rich protein IA & Sprrla & 3.64 & 0.046 \\
\hline 100884_at & aldo-keto reductase family I, member B8 & Akrlb8 & 2.89 & 0.001 \\
\hline 102993_at & glycoprotein galactosyltransferase alpha I, 3 & Ggtal & 2.88 & 0.016 \\
\hline I01794_f_at & defensin-related cryptdin 23 & Defcr23 & 2.56 & 0.034 \\
\hline 93755_at & resistin like beta & Retnlb & 2.00 & 0.015 \\
\hline
\end{tabular}

*The genes of defensin family are shown in bold font.

*** Fold change is defined as the ratio of the signal of SPF to that of GF. 
cryptdin family. When we applied the same criteria, there were 43 probe sets expressed at lower levels in SPF mice than in GF mice (Table 2). The list of decreased genes con- tains 11 genes whose expression has been reported to be induced by type-1 interferon. Table 1 lists glycoprotein galactosyltransferase-alpha 1,3 (Ggta1) and Table 2 lists

Table 2: Genes more highly expressed in large intestines of GF mice than those in SPF mice

\begin{tabular}{|c|c|c|c|c|}
\hline Probe Set ID & Gene Name & Gene Symbol & Fold change* & p-value \\
\hline \multicolumn{5}{|c|}{ Type I interferon-related genes } \\
\hline 104750_at & interferon gamma inducible protein 47 & Ifi47 & 5.13 & 0.003 \\
\hline 103639_at & interferon-induced protein with tetratricopeptide repeats 2 & Ifit2 & 4.87 & 0.009 \\
\hline 102906_at & T-cell specific GTPase & Tgtp & 3.99 & 0.036 \\
\hline I0098I_at & interferon-induced protein with tetratricopeptide repeats I & Ifit I & 3.81 & 0.013 \\
\hline 103202_at & guanylate nucleotide binding protein 4 & Gbp4 & 3.76 & 0.030 \\
\hline 104177_at & radical S-adenosyl methionine domain containing 2 & Rsad2 & 3.20 & 0.006 \\
\hline 97409_at & immunity-related GTPase family, M & Irgm & 3.03 & 0.008 \\
\hline $101465 \_a t$ & signal transducer and activator of transcription I & Statl & 2.63 & 0.025 \\
\hline 104669_at & interferon regulatory factor 7 & Irf7 & 2.58 & 0.022 \\
\hline 103335_at & lectin, galactose binding, soluble 9 & Lgals9 & 2.26 & 0.042 \\
\hline 104597_at & guanylate nucleotide binding protein 2 & Gbp2 & 2.15 & 0.035 \\
\hline \multicolumn{5}{|c|}{ Immunoglobulins } \\
\hline 96969_at & similar to Ig V-KI67 precursor & LOC38I776 & 7.39 & 0.014 \\
\hline 93904_f_at & similar to Ig H-chain (VDJ-region) precursor & LOC2384I8 & 6.11 & 0.023 \\
\hline 101320_f_at & $\begin{array}{l}\text { similar to } \lg M(b) \text { heavy pre-chain }(\mathrm{AA}-18 \text { to } 119) / \text { similar to } \\
\text { anti-poly }(\mathrm{dC}) \text { monoclonal antibody heavy chain/similar to } \\
\text { immunoglobulin heavy chain/similar to Ig heavy chain } V \text { region } \\
3 \text { precursor/similar to monoclonal antibody heavy chain }\end{array}$ & VI65-D-J-C mu etc & 3.87 & 0.006 \\
\hline 93584_at & $\begin{array}{l}\text { immunoglobulin heavy chain } 6 \text { (heavy chain of IgM)/Unknown } \\
\text { (protein for MGC:60843) }\end{array}$ & Igh-6/MGC60843 & 2.57 & 0.041 \\
\hline 97575_f_at & $\begin{array}{l}\text { Immunoglobulin heavy chain Ia (serum IgG2a), mRNA } \\
\text { (cDNA clone MGC:6529 IMAGE:265 I493) }\end{array}$ & lgh-VJ558 & 2.33 & 0.011 \\
\hline 93638_s_at & immunoglobulin lambda chain, variable I & $|g|-V \mid$ & 2.25 & 0.017 \\
\hline \multicolumn{5}{|c|}{ Other molecules } \\
\hline 103957_at & transferrin receptor & Tfrc & 6.84 & 0.001 \\
\hline 160986_r_at & angiotensin I converting enzyme (peptidyl-dipeptidase A) 2 & Ace2 & 5.13 & 0.040 \\
\hline 92699_at & $\begin{array}{l}\text { solute carrier family } 7 \text { (cationic amino acid transporter, } y^{+} \\
\text {system), member } 9\end{array}$ & Slc7a9 & 4.45 & 0.014 \\
\hline 96792_at & apolipoprotein B & Apob & 3.60 & 0.022 \\
\hline 160933_at & interferon gamma induced GTPase & lgtp & 3.39 & 0.003 \\
\hline 94936_at & meprin I beta & Meplb & 3.33 & 0.011 \\
\hline 96912_s_at & $\begin{array}{l}\text { cytotoxic T lymphocyte-associated protein } 2 \text { alpha/cytotoxic } \\
\text { T lymphocyte-associated protein } 2 \text { beta }\end{array}$ & Ctla2a/Ctla2b & 3.30 & 0.000 \\
\hline 102373_at & glutamyl aminopeptidase & Enpep & 3.13 & 0.008 \\
\hline 100030_at & uridine phosphorylase I & Uppl & 3.10 & 0.006 \\
\hline 98994_at & solute carrier family 34 (sodium phosphate), member 2 & Slc34a2 & 3.05 & 0.012 \\
\hline 98410_at & interferon inducible GTPase 2 & ligp2 & 2.91 & 0.007 \\
\hline 92689_at & interleukin 18 binding protein & III8bp & 2.82 & 0.021 \\
\hline 103025_at & Moloney leukemia virus 10 & Movi0 & 2.79 & 0.035 \\
\hline 97950_at & xanthine dehydrogenase & Xdh & 2.74 & 0.016 \\
\hline 102559_at & bone morphogenetic protein 2 & Bmp2 & 2.49 & 0.020 \\
\hline 96764_at & interferon inducible GTPase I & ligpl & 2.48 & 0.001 \\
\hline 94088_at & polypyrimidine tract binding protein 2 & Ptbp2 & 2.42 & 0.012 \\
\hline 97500_g_at & four and a half LIM domains I & Fhll & 2.32 & 0.049 \\
\hline 98958_at & enhancer of yellow 2 homolog (Drosophila) & Eny2 & 2.30 & 0.021 \\
\hline 103250_at & deafness, autosomal dominant 5 homolog (human) & Dfna5h & 2.26 & 0.042 \\
\hline 97994_at & transcription factor $7, \mathrm{~T}$-cell specific & Tcf7 & 2.25 & 0.026 \\
\hline 92877_at & transforming growth factor, beta induced & Tgfbi & 2.23 & 0.023 \\
\hline 102965_at & expressed sequence Al48I I05 & Al48II 05 & 2.17 & 0.019 \\
\hline 104606_at & CD52 antigen & $\mathrm{Cd} 52$ & 2.15 & 0.004 \\
\hline 99463_at & cytochrome P450, family 3 , subfamily a, polypeptide 13 & Сyp3al3 & 2.14 & 0.011 \\
\hline 99993_at & alanyl (membrane) aminopeptidase & Anpep & 2.08 & 0.017 \\
\hline
\end{tabular}

\footnotetext{
* Fold change is defined as the ratio of the signal of GF to that of SPF.
} 
Ifit1/GARG16, and four and a half LIM domains 1 (Fhl1), which have been noted to change in SPF mice or colonized GF mice in previous reports $[20,28]$. However, there are only a few additional genes, whose function is considered to be "professionally" immune-related.

Verification of the changes in gene expression by RT-PCR We next attempted to confirm the GeneChip data by using quantitative real time RT-PCR. Because the cryptdin family consists of more than 20 genes with DNA sequences of extraordinarily high homology, we determined the gene identity by DNA sequencing. The RT-PCR fragments amplified using the primers common for the cryptdin family were cloned into pT7Blue vector. DNA sequencing has suggested that the members of cryptdin family predominantly expressed in the colon of IQI GF and SPF mice are all cryptdin-related sequences; i.e. Defcr-rs 4, 2, and 7 (40, 7, 10 of GF mice-derived 62 clones and 24, 15, 16 of SPF-mice derived 61 clones, respectively). No authentic cryptdins were found among the sequences of the aforementioned 123 clones. Because of the difficulties in designing the primer/probe sets, due to extremely high sequence homology among these genes, further investigation using quantitative RT-PCR has not been done.

When we extended the criteria to genes with a greater than 1.5 -fold ratio of expression in GF mice as compared with SPF mice, an additional class of immune-related genes were identified; namely, complement-related genes and MHC-related genes. The latter contains non-classical MHC class $1 \mathrm{~b}$ genes which are known to be monomorphic or oligomorphic and expressed in a limited number of tissues, such as thymus and intestinal epithelium $[29,30]$. Furthermore, MHC I genes are known to be type 1 IFN-inducible genes whose promoter regions contain typical interferon stimulus response elements (ISREs) $[31,32]$. In addition to the immune-related genes listed in Table 2, additional genes (for example, several interferon regulatory factors, IFN- $\alpha$-inducible genes and IFN receptors) were assessed by RT-PCR analysis (Table 3) to obtain a more detailed picture of the changes in type 1 IFNrelated molecules. The expression of IFN- $\alpha \mathrm{s}(\alpha 1, \alpha 2, \alpha 4)$, the end products of these signaling cascades, has also been analyzed but expression of IFN- $\alpha$ s was not detected in either SPF or GF mice (data not shown).

\section{Verification study using microflora-reconstituted (ex-GF) mice}

To verify whether the observed changes were attributable to the presence of intestinal flora, we examined gene expression in microbiota-reconstituted mice. Pregnant GF mice were cohabited with SPF mice beginning 3 to 5 days before delivery. The offspring was kept under SPF conditions until the age of 9 weeks and total RNA was prepared from the large intestine. Real time RT-PCR was performed, the results of which are shown in Table 4. Significant changes in gene expression were generally similar to those presented in Table 3.

\section{Production of type I interferon in the small and large intestines}

To investigate whether IFN-related genes play a significant role in the immune defense response in the large intestine, we administered an oral interferon inducer, R11567DA, and used ELISA to determine the amount of IFN- $\alpha$ produced in the small intestine, large intestine, and blood. As shown in Figure 1, after 4 hours, high levels of IFN- $\alpha$ were detected in homogenates of large intestine but not in small intestine or serum. After 20 hours, IFN- $\alpha$ was also detected in the small intestine and serum, and at higher levels than in large intestine. These data suggest that the large intestine can produce IFN- $\alpha$ very rapidly, prior to the elevation of blood IFN- $\alpha$ levels, even before the commencement of IFN- $\alpha$ production in the small intestine, which contains an abundance of IFN-signaling molecule mRNAs and would likely encounter the oral IFN inducers earlier than would the large intestine.

\section{In situ hybridization}

To elucidate the cell types responsible for R11567DAinduced IFN- $\alpha$ production, we performed in situ hybridization on sections prepared from the small and large intestines with or without 4-hour R11567DA treatment in SPF mice (Figure 2 and Figure 3). In situ hybridization with an IFN- $\alpha 1$-specific probe revealed that IFN- $\alpha 1$ was expressed in Paneth cells, the small intestine, and discrete cells distributed in the lamina propria in the large intestine. Similar results have been obtained with probes for other types of IFN- $\alpha$-induced genes, such as Ifit1, Irf7 (Figure 2) and oas1g (data not shown). The localization of Tlr7 mRNA, which has been shown to be expressed in a limited number of cell types, including plasmacytoid dendritic cells $[33,34]$, showed a similar distribution pattern to that of the aforementioned IFN-related genes. Both at 4 and 20 hours, the number of IFN- $\alpha$ mRNA positive cells per mucosal area in the small intestine was larger than that in the large intestine (Figure 3). However, at 4 hours, R11567DA treatment increased the number of IFN- $\alpha$-positive cells in the large intestine but not in the small intestine (Figure 3), which is in good accordance with the results of our IFN- $\alpha$ ELISA. The number of Ifit1-positive cells was increased by R11567DA treatment in both the small and large intestine, while the increase in the number of Irf7-positive cells occurred only in the small intestine. The number of Oas1g and Tlr7 did not change in either the small or large intestine following R11567DA treatment. At 20 hours, in the small intestines of R1156DAtreated mice, the number of IFN- $\alpha$ and Irf7-positive cells increased as compared with the control group, while no difference was seen in the large intestines. The number of 
Table 3: Verification of the changes in gene expression by quantitative realtime RT-PCR

\begin{tabular}{|c|c|c|c|c|c|}
\hline \multirow[t]{2}{*}{ Gene Name* } & \multirow[t]{2}{*}{ Gene Symbol } & \multicolumn{2}{|c|}{ qt realtime $R T-P C R$} & \multirow{2}{*}{$\begin{array}{c}\text { GeneChip } \\
\text { significant difference }\end{array}$} & \multirow{2}{*}{$\begin{array}{l}\text { RT-PCR primer/probe ID**** } \\
\text { GeneChip Probe Set ID }\end{array}$} \\
\hline & & Fold change ${ }^{* *}$ & $P$ value & & \\
\hline \multicolumn{6}{|l|}{ Type I interferon-regulatory factors } \\
\hline interferon regulatory factor I (IRFI) & IrfI & 1.00 & - & - & Mm005I5I9I_ml I0240I_at \\
\hline interferon regulatory factor 3 (IRF3) & Irf3 & 1.06 & 0.479 & - & Mm005I6779_ml 99103_at \\
\hline interferon regulatory factor 5 (IRF5) & Irf5 & 2.38 & 0.112 & - & Mm00496477_ml 93425_at \\
\hline interferon regulatory factor 6 (IRF6) & Irf6 & 1.50 & 0.363 & - & Mm005I6797_ml 92440_at \\
\hline interferon regulatory factor 7 (IRF7) & Irf7 & 2.44 & 0.031 & + & Mm00516788_ml 104669_at \\
\hline $\begin{array}{l}\text { interferon dependent positive acting } \\
\text { transcription factor } 3 \text { gamma(IRF9) }\end{array}$ & Isgf3g & 2.53 & 0.001 & - & Mm00492679_ml 103634_at \\
\hline interferon consensus sequence binding protein I(IRF8) & Irf8 & 1.11 & 0.299 & - & Mm00492567_ml 98002_at \\
\hline \multicolumn{6}{|l|}{ Type I interferon-inducible genes } \\
\hline $\begin{array}{l}\text { interferon-induced protein with } \\
\text { tetratricopeptide repeats I }\end{array}$ & Ifitl & 5.22 & 0.048 & + & Mm005I5I53_ml 10098I_at \\
\hline $\begin{array}{l}\text { interferon-induced protein with tetratricopeptide } \\
\text { repeats } 2\end{array}$ & Ifit2 & 0.82 & 0.861 & + & Mm00492606_ml 103639_at \\
\hline $\begin{array}{l}\text { glucocorticoid-attenuated response gene } 49 \text { (GARG-49/ } \\
\text { IRG2) }\end{array}$ & Ifit3 & 1.99 & 0.195 & - & Mm01704846_sl 93956_at \\
\hline guanylate nucleotide binding protein 2:mGBP-2 & Gbp2 & 2.83 & 0.091 & + & Mm00494575_ml 104597_at \\
\hline expressed sequence Al48I 100:GTPI & ligp2 & 2.11 & 0.060 & + & Mm00546343_sl 96764_at \\
\hline chemokine ( $\mathrm{C}-\mathrm{X}-\mathrm{C}$ motif) ligand I0:IP-I0 & Cxcllo & 4.69 & 0.058 & - & Mm00445235_ml 93858_at \\
\hline interferon inducible protein I:LRG-47, Ifi I & Irgm & 6.30 & 0.188 & + & Mm00492596_ml 97409_at \\
\hline lectin, galactose binding, soluble 9 & Lgals9 & 1.96 & 0.023 & + & Mm00495295_ml 103335_at \\
\hline interferon gamma induced GTPase & lgtp & 2.95 & 0.012 & + & Mm004976II_ml I60933_at \\
\hline \multicolumn{6}{|l|}{ Type I interferon receptors } \\
\hline interferon (alpha and beta) receptor I & Ifnar I & 0.29 & 0.424 & - & Mm00439544_ml 100483_at \\
\hline interferon (alpha and beta) receptor 2 & Ifnar2 & 1.12 & 0.599 & + & Mm00494916_ml 101014_at \\
\hline \multicolumn{6}{|l|}{ Complement-related genes } \\
\hline $\begin{array}{l}\text { complement component I, q subcomponent, alpha } \\
\text { polypeptide }\end{array}$ & Clqa & 2.24 & 0.105 & + & Mm00432I42_ml 98562_at \\
\hline complement component 3 & $\mathrm{C} 3$ & 2.74 & 0.059 & + & Mm00437858_ml 93497_at \\
\hline $\begin{array}{l}\text { serine (or cysteine) proteinase inhibitor, clade G, } \\
\text { member I:complement I inhibitor }\end{array}$ & Serping I & 1.41 & 0.070 & + & Mm00437834_ml 9908I_at \\
\hline \multicolumn{6}{|l|}{ MHC-related genes } \\
\hline Histocompatibility 2, class II antigen A, alpha & $\mathrm{H} 2-\mathrm{Aa}$ & 1.73 & 0.197 & + & Mm0160933I_ml 92866_at \\
\hline MHC class II H2-I-A-beta gene (k haplotype) & $\mathrm{H} 2-\mathrm{ABI}$ & 1.82 & 0.022 & + & H2-ABI-TG04 100998_at \\
\hline MHC (A.CA/J(H-2K-f) class I antigen & H2-QI & 0.88 & 0.496 & + & Mm00657093_gl 97125_f_at \\
\hline MHC class I Q4 beta-2-microglobulin (Qb-I) gene & $\mathrm{H} 2-\mathrm{Q} 4$ & 1.65 & 0.008 & - & H2-Q4-TG09 99378_f_at \\
\hline Q8/9d gene & LOC386462 & 2.22 & 0.017 & + & H2-Q78-TG08 98438_f_at \\
\hline Histocompatibility $2, T$ region locus $10+17$ & H2-TI0/22/9 & 1.74 & 0.114 & + & H2-TI0I7-TGII 93865_s_at \\
\hline Histocompatibility 2, T region locus 23 & $\mathrm{H} 2-\mathrm{T} 23$ & 1.35 & 0.116 & + & Mm00439246_gl 98472_at \\
\hline \multicolumn{6}{|l|}{ Other molecules } \\
\hline $\begin{array}{l}\text { cytotoxic T lymphocyte-associated protein } 2 \\
\text { alpha }\end{array}$ & Ctla2a & 5.17 & 0.002 & + & Mm00484032_gl 96912_s_at \\
\hline CD52 antigen:CD80? & Cd52 & 2.40 & 0.029 & + & Mm00489055_ml 104606_at \\
\hline
\end{tabular}

* The genes giving a significant $(\mathrm{p}<0.05)$ result in the real-time RT-PCR were shown in bold font.

** Fold change is defined as the ratio of the signal of GF to that of SPF.

**** The primer probe sets were perchased from TaqMan Gene Expression Assays (Applied Biosystems) except for those for H2-ABI, H2-Q4, LOC386462, and H2-TI0/22/9, which were synthesized by Costum TaqMan gene expression assay (Appried Byosystems) using File Builder program (Applied Byosystems). The primer-probe IDs in TaqMan Gene Expression Assays were shown in the table. The sequences of the primerprobe sets in Custom TaqMan gene expression assay are the following.

H2-ABI-TG04 forward; 5'-CCTGAAGAGCCCCATCACT-3', reverse; 5'-CTTGCTCCGGGCAGACT-3', probe 5'-

ACTGTGCCCTCCACTCCA-3'

H2-Q4-TG09 forward;5'-CCTGGAGCTCGGGAAGGA-3', reverse; 5'-CCGTCAGATCTGTGGTGACATG-3', probe; 5'ACAGATCCTCCAAAGGCA-3'

H2-Q78-TG08 forward; 5'-AGGGCCATGAGCAGAGTTTC-3', reverse; 5'-CCCCATGTCACAGCCATACA-3', probe; 5'AAGGGCGGCTCTCACA 3

H2-TI 0 I 7-TG I I forward; 5'-ACGTGCCATGTGGACCAT-3', reverse 5'-GCAACAATCCAAATCCAAGGCTTTT-3', probe; 5'CAGGCTCCCATCTCAG-3' 
Tlr7-positive cells decreased in the large intestine at 20 hours.

\section{Immunohistochemistry}

To identify the cells responsible for R11567DA-induced IFN- $\alpha$ production, we performed immunohistochemistry on sections prepared from the large intestines with or without 4-hour R11567DA treatment in SPF mice. The antibody to ISG15, a typical type-1 interferon-stimulated gene stained discreet single cells or relatively small cell aggregates in the lamina propria in R11567DA-treated colons (Figure 4A). No signal was detected in the epithelial layers. Multiple staining by combinations of antibodies including dendritic cell markers revealed that in the large intestine ISG15 was produced in a small proportion of CD11 b ${ }^{+}$cells (Figure 4B, C, E) and mPDCA1+ cells (Figure $4 \mathrm{E}$ ) although more than half of the ISG15+ cells were not stained by either CD11b or mPDCA1 antibody. Virtually no ISG $15^{+}$cells were found among the $\mathrm{CD} 11 \mathrm{c}^{+}$cells (Figure 4D).

\section{Discussion}

In the present study, transcriptome analysis was performed on colon tissue. This approach to profile transcription in whole tissues may be limited in that the detected changes are derived from composite changes in plural cell types. However, previous transcriptome studies that have focused on intestinal epithelial cells (IECs) $[20,28]$ did not appear to adequately characterize the microflora-induced immunological changes in terms of transcriptional profiling, even in the small IECs, the physiology of which is supposed to be profoundly affected by a variety of GALT-derived cells and/or mediators. Although recent studies have revealed a wide array of immune-oriented functions of IECs [35,36], the spectrum of immune functions carried out by IECs is limited. By analyses of gene expression using whole colons from commensal GF mice, certain bacteria have been reported to increase the expression of IFN- $\gamma$-related genes and immunoglobulins $[14,15,21]$.

In the present study, the expression of CRSs was increased by commensal bacteria. CRSs are cationic peptides that have a pro-region with high similarity to the pro-region of $\alpha$-defensins. Although mature CRS peptides have no sequence homology or structural homology to any other known anti-microbial peptides, CRSs have been reported to co-localize with cryptdins in the granules of Paneth cells in similar amounts to cryptdins and to have potent microbial bacteriacidal activity [37-39]. A previous study using the differential display technique showed higher expression of CRS4C in the small intestines of SPF ICR mice than of GF ICR mice [40]. If CRSs function as the first-line defense against microbial invasion, like other various intestinal anti-microbial peptides, it is reasonable that the expression of CRSs in the small and large intestines of SPF mice is higher than that of GF mice. However, apparently normal colons do not have Paneth cells, which are the main sites of cryptdin and CRS localization in the small intestine. Although metaplastic Paneth cells expressing antimicrobial proteins such as cryptdins and lysozymes are known to appear in inflammed colons $[41,42]$, histological examination detected no such cells in the large intestines of SPF mice (data not shown). Because cryptdins have been reported to also be present in the epithelial cells of the small intestines [40], CRSs may be expressed in the colonic epithelium. The localization and biological implication of CRSs remains to be elucidated in future research.

The most interesting finding of the present study is the possible importance of IFN- $\alpha$ in the defense systems of the large intestine. The most prominent difference in the expression of professional immune molecules was observed for genes involved in the IFN- $\alpha$ induction pathway. Many of them, such as Ifit1, 2 [43], Ifi47 [44], Tgtp [45], Gbp2 and 4 [46], Irgm [47]. Lgals9 [48], and Rsad2 [49] were originally identified as IFN- $\alpha$-inducible genes. One molecule, Irf7, is a rate limiting transcription factor located in the center of a self-amplifying positive feedback loop of massive IFN- $\alpha$ production [50]. Microbial infection induces phosphorylation of IRF7 protein, and phosophorylated IRF7 is transported into nuclei to strongly induce the expression of IFN- $\alpha$ s and Irf7 itself. In the presence of kinase activated by infectious agents, newly synthesized IRF7 continues to activate the loop resulting in the explosive production of IFN-as. The inducibility of IFN- $\alpha$ production in various tissues/cells and their steady state level of IRF7 proteins are known to be closely correlated [51]. Isgf3g (Irf9) and Stat1 are 2 components of ISGF3, a signaling complex that transduces the signal from receptors of IFN- $\alpha / \beta$ and induces the expression of IFN- $\alpha$-related molecules including double-stranded RNAdependent kinase Eif2ak2 (Prkr) [52], 2'-5' oligozdenylate synthetase 1A (Oas1a or Oas1g) [53], ISG15 ubiquitinlike modifier (G1p2 or Isg15) [54], and especially, Stat1 and Irf7 [55]. Changes in the expression of Stat2, the other component of ISGF3, have also been observed. In contrast, the expression of other interferon regulatory factors such as Irf1, Irf2, and Irf8 did not show differences, and expression of end-products such as the IFN- $\alpha$ s, a2 and a4 was not detected. These data suggest that, although GF and SPF mice usually do not express IFN- $\alpha$, or do so at extremely low levels, once the stimulatory signals are triggered, they might produce different levels of IFN- $\alpha$ due to the difference in basal expression levels of rate-limiting regulatory factors of IFN- $\alpha$ production.

It is unknown, among the wide array of signaling molecules involved in IFN- $\alpha$ production, why only the rela- 
Table 4: Changes in gene expression of flora-reconstituted mice (quantitative realtime RT-PCR)

\begin{tabular}{|c|c|c|c|c|}
\hline \multirow[t]{2}{*}{ Gene Name* } & \multirow[t]{2}{*}{ Gene Symbol } & \multicolumn{2}{|c|}{ qt realtime $\mathrm{RT}-\mathrm{PCR}$} & \multirow{2}{*}{$\begin{array}{c}\text { RT-PCR } \\
\text { primer/probe ID*** }\end{array}$} \\
\hline & & Fold change** & $P$ value & \\
\hline \multicolumn{5}{|l|}{ Type I interferon-reguratory factors } \\
\hline interferon regulatory factor I (IRFI) & Irfl & 1.00 & - & Mm005I5I9I_ml \\
\hline interferon regulatory factor 3 (IRF3) & Irf3 & 1.84 & 0.003 & Mm005I6779_ml \\
\hline interferon regulatory factor 5 (IRF5) & Irf5 & 3.05 & 0.053 & Mm00496477_ml \\
\hline interferon regulatory factor 6 (IRF6) & Irf6 & 6.47 & 0.055 & Mm005I6797_ml \\
\hline interferon regulatory factor 7 (IRF7) & Irf7 & 4.42 & $<0.001$ & Mm005I6788_ml \\
\hline $\begin{array}{l}\text { interferon dependent positive acting transcription factor } 3 \\
\text { gamma(IRF9) }\end{array}$ & Isgf3g & 2.87 & 0.033 & Mm00492679_ml \\
\hline interferon consensus sequence binding protein I(IRF8) & Irf8 & 1.89 & 0.043 & Mm00492567_ml \\
\hline \multicolumn{5}{|l|}{ Type I interferon-inducible genes } \\
\hline interferon-induced protein with tetratricopeptide repeats I & Ifit l & 4.13 & 0.029 & Mm005I5I53_ml \\
\hline interferon-induced protein with tetratricopeptide repeats 2 & Ifit2 & 5.18 & 0.233 & Mm00492606_ml \\
\hline glucocorticoid-attenuated response gene 49 (GARG-49/IRG2) & Ifit3 & 12.77 & 0.095 & Mm0I704846_sl \\
\hline guanylate nucleotide binding protein 2:mGBP-2 & Gbp2 & 3.66 & 0.069 & Mm00494575_ml \\
\hline expressed sequence Al48 I I 00:GTPI & ligp2 & 4.43 & 0.008 & Mm00546343_sl \\
\hline chemokine (C-X-C motif) ligand I0:IP-10 & Cxcllo & 14.33 & 0.133 & Mm00445235_ml \\
\hline interferon inducible protein I:LRG-47, Ifil & Irgm & 7.14 & 0.177 & Mm00492596_ml \\
\hline lectin, galactose binding, soluble 9 & Lgals9 & 4.03 & 0.008 & Mm00495295_ml \\
\hline interferon gamma induced GTPase & lgtp & 3.22 & 0.132 & Mm004976II_ml \\
\hline IFN- type I-induced and dsRNA-activated kinase & Eif2ak2 & 2.07 & 0.040 & Mm00440966_ml \\
\hline 2'-5' oligoadenylate synthetase IA & Oasla & 3.18 & 0.046 & Mm008364I2_ml \\
\hline 2'-5' oligoadenylate synthetase IB & Oaslb & 13.05 & 0.052 & Mm00449297_ml \\
\hline TAP binding protein & Tapbp & 1.86 & 0.046 & Mm004934l7_ml \\
\hline \multicolumn{5}{|l|}{ Type I interferon receptors } \\
\hline interferon (alpha and beta) receptor I & Ifnar I & 1.84 & 0.017 & Mm00439544_ml \\
\hline interferon (alpha and beta) receptor 2 & Ifnar2 & 2.06 & 0.010 & Mm004949l6_ml \\
\hline \multicolumn{5}{|l|}{ Complement-related genes } \\
\hline complement component I, q subcomponent, alpha polypeptide & $\mathrm{Clqa}$ & 1.87 & 0.178 & Mm00432I42_ml \\
\hline complement component 3 & $\mathrm{C} 3$ & 2.08 & 0.141 & Mm00437858_ml \\
\hline $\begin{array}{l}\text { serine (or cysteine) proteinase inhibitor, clade G, member I: } \\
\text { complement I inhibitor }\end{array}$ & Serpingl & 2.18 & 0.005 & Mm00437834_ml \\
\hline \multicolumn{5}{|l|}{ MHC-related genes } \\
\hline Histocompatibility 2, class II antigen A, alpha & $\mathrm{H} 2-\mathrm{Aa}$ & 2.72 & 0.266 & Mm0I60933I_ml \\
\hline MHC class II H2-I-A-beta gene (k haplotype) & $\mathrm{H} 2-\mathrm{ABI}$ & 3.42 & 0.041 & $\mathrm{H} 2-\mathrm{ABI}-\mathrm{TG} 04$ \\
\hline MHC (A.CA $/ J(H-2 K-f)$ class I antigen & H2-QI & 3.47 & 0.356 & Mm00657093_gl \\
\hline MHC class I Q4 beta-2-microglobulin (Qb-I) gene & $\mathrm{H} 2-\mathrm{Q} 4$ & 3.83 & 0.032 & H2-Q4-TG09 \\
\hline Q8/9d gene & LOC386462 & 11.69 & 0.153 & H2-Q78-TG08 \\
\hline Histocompatibility $2, T$ region locus $10+17$ & $\mathrm{H} 2-\mathrm{T} 10 / 22 / 9$ & 8.06 & 0.006 & H2-TIOI7-TGII \\
\hline Histocompatibility 2, T region locus 23 & $\mathrm{H} 2-\mathrm{T} 23$ & 1.10 & 0.762 & Mm00439246_gl \\
\hline \multicolumn{5}{|l|}{ Other molecules } \\
\hline cytotoxic $\mathrm{T}$ lymphocyte-associated protein 2 alpha & Ctla2a & 9.48 & 0.139 & Mm00484032_gl \\
\hline CD52 antigen & $\mathrm{Cd} 52$ & 3.05 & 0.095 & Mm00489055_ml \\
\hline signal transducer and activator of transcription I & Statl & 4.66 & 0.026 & Mm00439518_ml \\
\hline signal transducer and activator of transcription 2 & Stat2 & 3.81 & 0.015 & Mm00490880_ml \\
\hline
\end{tabular}

* The genes giving a significant $(\mathrm{p}<0.05)$ result in the real-time RT-PCR were shown in bold font.

*** Fold change is defined as the ratio of the signal of GF to that of SPF.

**** See the legend of Table 3.

tively confined members showed differences in the present study. One possible explanation was provided by the results of IFN- $\alpha$ induction experiments. Administration of oral IFN- $\alpha$ inducers resulted in elevated tissue IFN$\alpha$ content in both the small and large intestines. However, in spite of the high basal levels of IFN- $\alpha$-related genes, including Irf7, the production of IFN- $\alpha$ in the small intes- tine occurred later than in the large intestines. The extreme rapidness of IFN production in the large intestine suggests a possible involvement of Type 1 interferon producing cells (IPCs), which are virtually identical to plasmacytoid dendritic cells (pDCs) [56]. IPCs express extremely high levels of Irf7 mRNA and protein constitutively, and can produce 100 to 1000 times more IFN than 

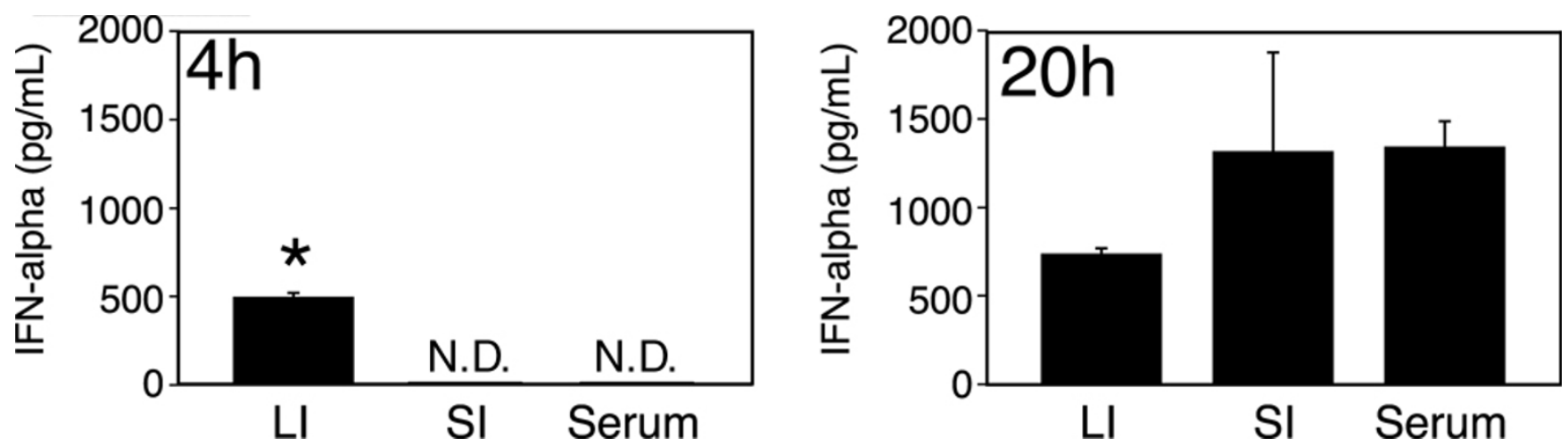

Figure I

The content of IFN- $\alpha$ s after RI I567DA administration. Four hours after oral administration of RI I567DA at I00 mg/ $\mathrm{kg}$, the small and large intestines were removed, homogenized, and centrifuged. The amounts of IFN- $\alpha$ s were measured by ELISA as described in Materials and Methods. Data represent mean \pm SEM $(n=3)$. LI, large intestine; SI, small intestine, N.D., not detected (under detection limit), *, $\mathrm{p}<0.000$ I vs SI. Without RI I567DA treatment, IFN- $\alpha$ s were not detected in any tissues or sera. This experiment was repeated twice with similar results.

other blood cell types within several hours following stimulation.

This assumption was further supported by our in situ hybridization analysis using specific probes against the IFN- $\alpha$-inducible genes, Ifnal, Ifit, Irf7, and Oas1g, and the plasmacytoid dendritic cell marker Tlr7. In the small intestine, histological analysis clearly indicated that the cells which had positive signals for type 1 IFN-related genes and Tlr7 were mainly Paneth cells. In the large intestine, all signals were located in the mononuclear cells scattered predominantly in the lamina propria, although further examination is necessary to determine whether these signals were generated from the same cells. In accordance with the results of our IFN- $\alpha$ ELISA, the number of Ifna1-positive cells increased in the large intestine but not in the small intestine at 4 hours. The increase in Irf7-positive cells in the small intestine may reflect amplification of the IRF7 pool, which is a prerequisite for massive IFN production in most cells types except for IPCs. In good agreement with the results of IFN- $\alpha$ ELISA at 20 hours, the numbers of IFN- $\alpha$ - and Irf7-positive cells increased in the small intestine. The increase in the number of these cells in the large intestine ceased at this time point, suggesting that the detected immunoreactive IFN- $\alpha$ might represent circulating IFN- $\alpha$ in the blood.

These data, collectively, address the possibility that IFN production and biological defense by IFN in the large intestine is borne mainly by IPCs, presumably recruited from the bloodstream to the intestinal lamina propria.

Finally, we performed immunohistochemical analysis to confirm whether the cells responsible for IFN- $\alpha$ production in the present study are IPCs/pDCs. We have screened several antibodies raised against type 1 IFN-related genes and found that the antibody for ISG15, a well-known IFNstimulated gene $[55,57]$, stained the cells in the lamina propria of the colon at 4 hours after IFN- $\alpha$ inducer treatment. Multiple staining by a combination of anti-ISG15 antibody and various $\mathrm{CD}$ markers has demonstrated that ISG15+ cells contains CD11 b+ cells and mPDCA1+ cells but not $\mathrm{CD} 11 \mathrm{c}^{+}$cells. Conventionally, pDCs (or IPCs) have been identified as $\mathrm{CD} 11 \mathrm{c}^{+} \mathrm{B} 220^{+} \mathrm{Gr}-1^{+}$cells or mPDCA $1^{+}$cells. However, recent studies suggested the phenotype of pDCs, especially in the peripheral tissues, may have a wide variation $[58,59]$. Takenaka S. et al [33] reported that, in the colons of $\mathrm{BALB} / \mathrm{C}$ and $\mathrm{C} 57 \mathrm{BL} / 6$ mice, many $\mathrm{mPDCA} 1^{+}$cells exist but they are neither $\mathrm{CD} 11 \mathrm{c}^{+}$ nor $\mathrm{CD} 11 \mathrm{~b}^{+}$, and no typical $\mathrm{CD} 11 \mathrm{c}^{+} \mathrm{B} 220^{+} \mathrm{Gr}-1^{+}$pDCs were present. These findings have also been obtained in the colons of IQI mice in our study (data not shown): 1) $\mathrm{CD} 11 \mathrm{~b}^{+}$cells were predominant in the colonic lamina propria; 2 ) the majority of mPDCA1+ cells was stained by neither anti-CD11b nor anti-CD11c antibodies; 3 ) typical pDCs (i.e., $\mathrm{CD} 11 \mathrm{c}^{+} \mathrm{B} 220^{+} \mathrm{Gr}-1^{+}$cells) were virtually absent. We have found that some $\mathrm{CD} 11 \mathrm{~b}^{+}$cells and mPDCA $1^{+}$cells were co-stained with anti-ISG15 antibody, but more than half of ISG15+ cells were double-negative for CD11b and mPDCA1. Colonic IPC may therefore be comprised of multiple cell populations with unique phenotypic characteristics distinct from conventional pDCs/ IPCs. Accordingly, IFN- $\alpha$ production in IBD model mice has been noted in both $\mathrm{CD} 11 \mathrm{~b}^{+}$and $\mathrm{CD} 11 \mathrm{c}^{+}$dendritic cells in colonic lamina propria [60]. However, the sensitivity and specificity of immunohistochemistry are limited and further extensive studies are necessary to clarify the functional and phenotypic characteristics of colonic IPCs. 


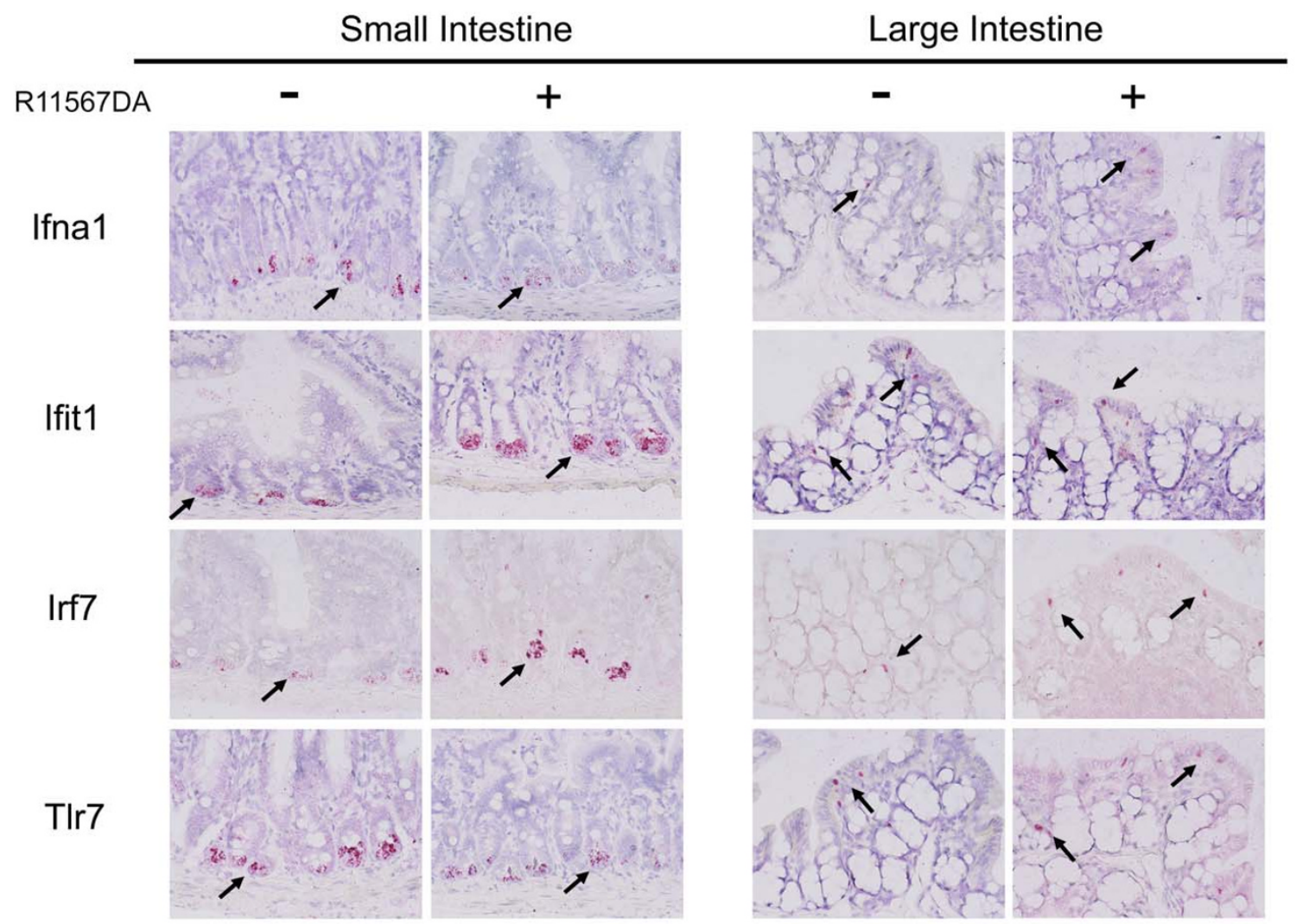

\section{Figure 2}

In situ hybridization for mRNAs of IFN- $\alpha$-related genes and TIr7 in the small and large intestines. A. Photomicrographs showing localization of Ifna I, Ifit I, Irf7 and TIr7. In the small intestine, all signals for Ifna I, Ifit I, Irf7 and TIr7 were detected in Paneth cells. In the large intestines, the signals were detected in the discrete cells distributed in lamina propria, though further examination is necessary to elucidate whether these signals were generated from the same cells, and to determine their cellular identity. Five sections per tissue were prepared from each of 8 mice. Representative photographs were shown.

Among the immune-related genes whose expression differed in the presence and absence of intestinal flora in the present GeneChip analysis, the IFN-related genes, MHCrelated genes, some complements, and immunoglobulins were expressed at lower levels in SPF mice than in GF mice. This seems somewhat paradoxical because it is plausible that contact with high levels of microorganisms in SPF mice may result in enhancement of certain immunological defense systems in the large intestine. Along this line, Chowdhury et al. [61] reported that the expression of IFN-related genes including Irf7, Stat1, Stat2 and Tap1 in the small intestines was increased by the colonization of GF piglets with adult conventional swine feces. The discrepancy between our data and theirs may be explainable by the differences in various experimental settings such as the host animal (mouse vs. swine), RNA source (large intestine tissue vs. small intestinal epithelial cell), microbial status (SPF vs. conventional), and age of animals (9 vs. 2 weeks old). However, we think that the difference in the period after colonization may be responsible for the difference in expression of IFN-related genes between our study and theirs. The inflammation induced by microbial colonization of GF animals has been known to be only temporary and cease within several weeks $[62,63]$. After the inflammation is terminated, histological findings return to a state apparently indistinguishable from the normal intestines of mice genuinely harboring the microbes. Therefore, the up-regulation of IFN-related genes in the midst of or shortly after inflammation, and their down-regulation after a long period of resumption of integrity of tissues and adaptation to enteric microbes may be quite compatible and it appears that the IFN sys- 


\section{$4 \mathrm{hr}$}

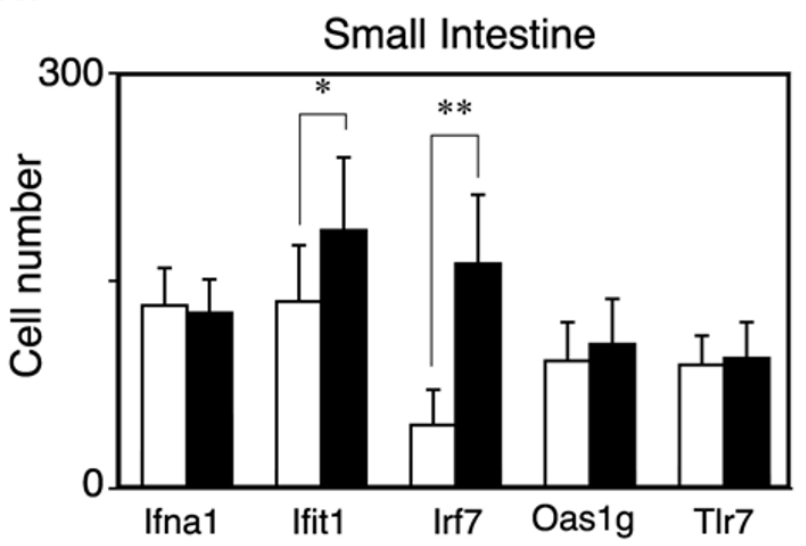

\section{$20 \mathrm{hr}$}

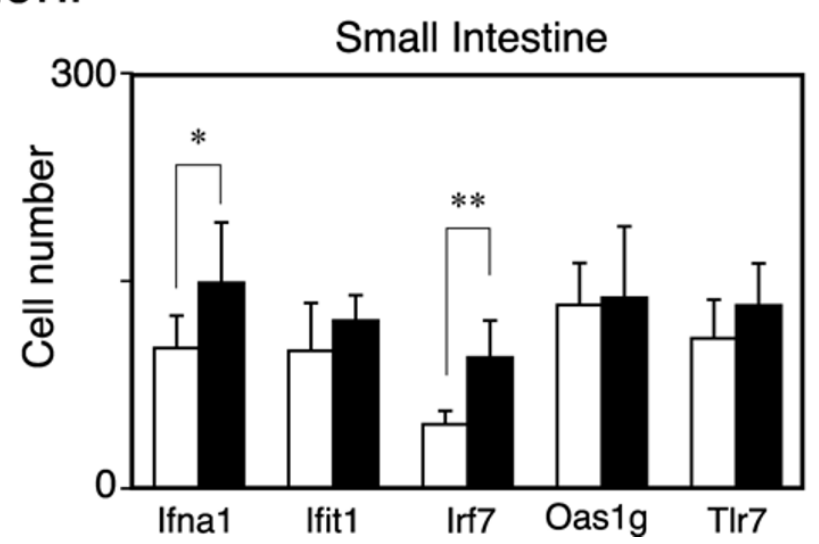

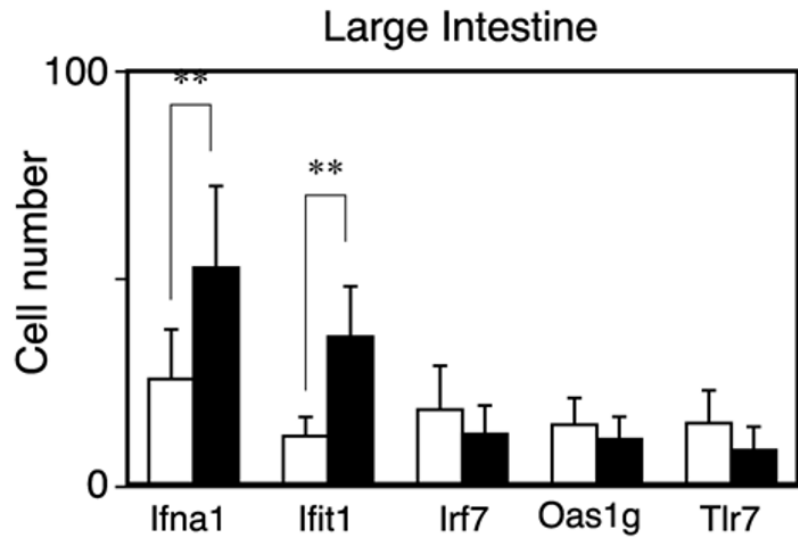

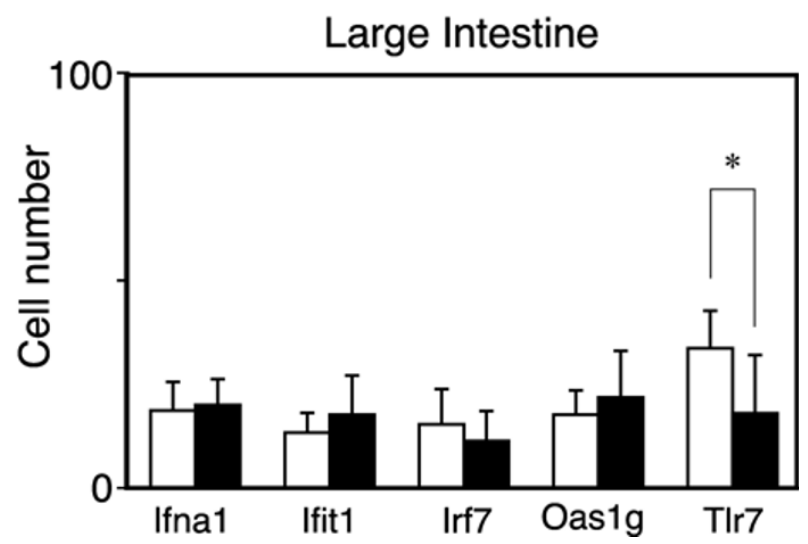

Figure 3

Quantitation of the numbers of cells positive for Ifna I, Irf7, Ifit I, Oas I g, or TIr7. Open and closed columns represent data obtained from saline- and RII567DA- treated mice, respectively. Sections prepared from 8 mice per group were used. Five low-power photographs were taken for each section, and the number of positive cells was counted and normalized to per $0.8 \mathrm{~mm}^{2}$ of intestinal mucosa. Data represent mean \pm SEM. $* P<0.05$, $* * P<0.0$ I, significantly different from the RII567DA (-) group.

tem may play an extraordinary role in the immunological confrontation, negotiation and reconciliation between microbiota and host animals. The immune systems of the gastrointestinal tract are known to have potent antiinflammatory and regulatory properties. In the intestinal immune systems, constant exposure to bacteria-derived immunostimulating molecules may crowd up the threshold of activation of the inflammatory aspect of the immune system. Alternatively, the immune system may be programmed to develop anti-inflammatory and/or regulatory responses to microbial stimuli as a default setting, unless certain specialized machinery such as toll-like receptors provide the additional signature indicating the stimuli are derived from specific dangerous pathogens. The down-regulation of immune-related genes may represent certain acquired characteristics of the intestinal immune systems to adapt to circumstances in which immune cells are continually exposed to vast amounts of commensal bacteria.

\section{Conclusion}

The present study suggests that microbial colonization, while inducing the expression of certain anti-microbial peptides, results in the down-regulation of a relatively limited range of genes responsible for host defense responses in the LI. This may reflect the adaptation process of immune systems in the LI to prevent excessive inflammation with respect to continuous microbial exposure. In particular, an extraordinary role of type I IFN has been suggested. Further, the repertoire of anti-microbial peptides and the extraordinary role of type 1 IFN-produc- 

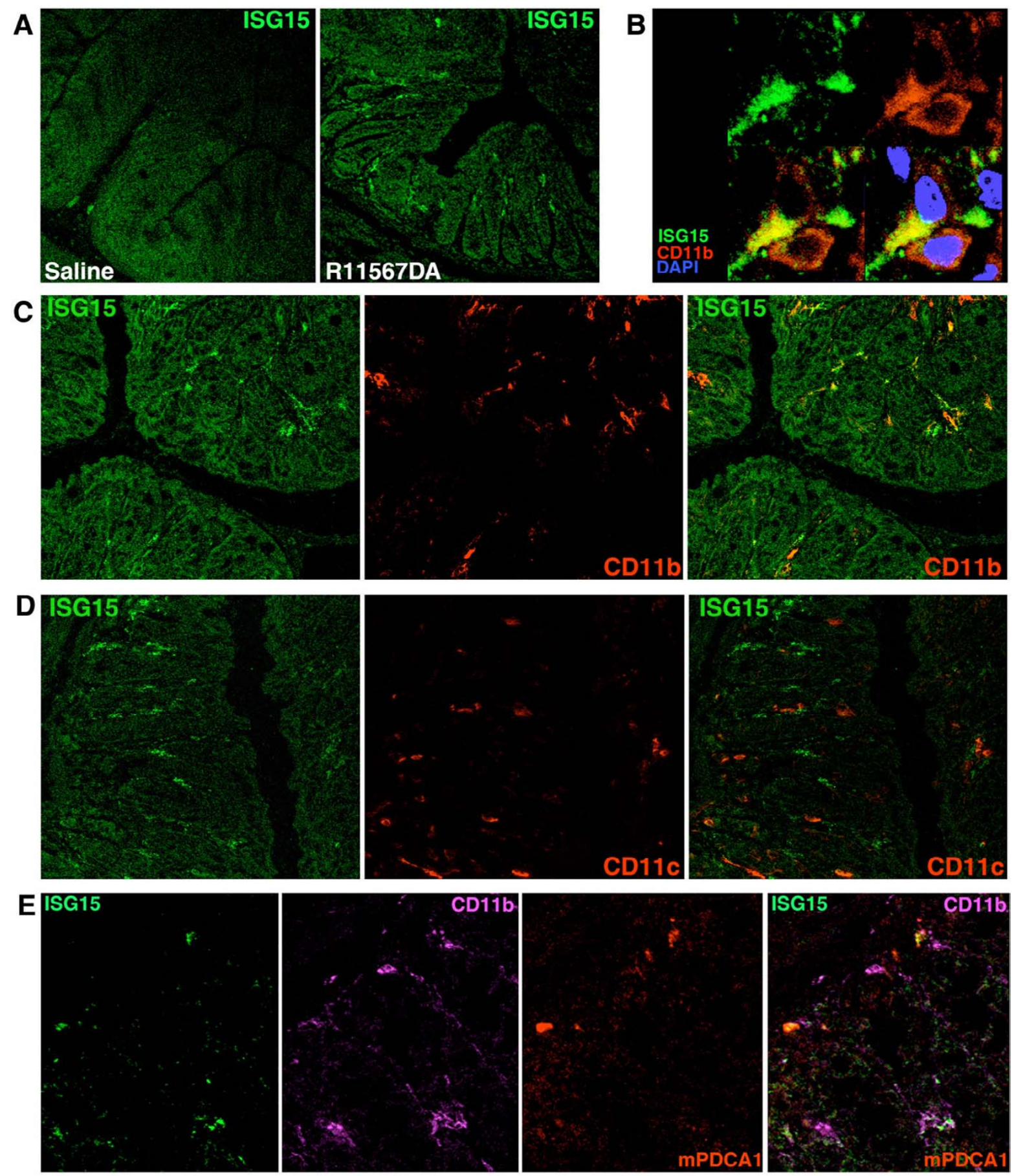

\section{Figure 4}

Immunofluorescence detection of IFN- $\alpha$ producing cells. Cryostat sections of colonic tissues from mice 4 hr after the administration of saline or RII567DA. Sections were multi-labeled with anti-ISG and anti-CDI Ib, anti-CDI Ic, anti-mPDCAI or DAPI. A, ISG I 5 signals were observed in colonic lamina propria of RII567DA-treated mice while saline treatment produced no signal. B, C. Portions of ISG I $5^{+}$cells (green) were co-stained (yellow) with anti-CDI Ib antibody (red). Nuclei were visualized by DAPI staining (blue) in Panel B. D, ISG I $5^{+}$CD I I c ${ }^{+}$double positive cells (yellow) were scarcely found. E, In addition to ISG I5+CDI Ib+ double-positive cells (yellow), ISG I5+mPDCAI+ double positive cells (white) were found. However, more than half of ISG I $5^{+}$cells was stained by neither anti-CDI Ib nor anti-mPDCAI antibodies (data not shown). 
ing cells in the LI have been found to be distinct from those in the SI.

\section{Methods \\ Animals}

Male germ-free (GF) and specific pathogen-free (SPF) IQI/ Jic mice were bred and maintained in the laboratory of the Central Institute for Experimental Animals (CIEA, Kawasaki, Kanagwa, Japan). GF mice were housed in a Trexlertype flexible film isolator in a standard germ-free state and screened on a weekly basis for germ-free status by sampling feces sterilely and culturing on MRS-agar plates under aerobic and anaerobic conditions. All GF-, SPF-, and ex-GF mice were kept on a 12:12-h light/dark cycle at a temperature of $22 \pm 2{ }^{\circ} \mathrm{C}$. Microflora reconstitution was performed by transferring the pregnant females to an SPF facility, where they were reared in the presence of male SPF mice beginning at 3 to 5 days before the expected natal day, and the newborn male mice were used as microflora-reconstituted ex-GF mice. All animal procedures were approved by the institution's ethical committee for care and use of laboratory animals in research.

\section{Tissue dissection}

Nine-week old mice were sacrificed by cervical dislocation and the colon was dissected (the colon was not divided into proximal and distal sections and was treated as a single intestinal section). Tissues destined for in situ hybridization were rinsed in phosphate-buffered saline (PBS), cut longitudinally, fixed in formalin or paraformaldehyde, and embedded in paraffin. Tissues destined for immunohistochemistry were embedded in OCT compound (Tissue-Tek, Sakura Finetechnical. Tokyo, Japan) and frozen in liquid nitrogen. Tissues destined for RNA extraction were flash-frozen in liquid nitrogen after washing with ice-cold PBS.

\section{Microarray analysis}

Total RNA was extracted from mice ( $\mathrm{n}=3$ per each group) using TRIzol (Life Technologies, Rockville, TX) and repurified by RNeasy spin columns (Qiagen, Valencia, CA), according to the manufacturer's instructions. All samples were monitored using an Agilent Bioanalyzer (Agilent Biotechnologies, Boeblingen, Germany) and consistently demonstrated high-quality RNA (28S/18S ratio, 2). The labeled cRNA prepared by in vitro transcription (Enzo Biochem, New York, NY) was fragmented, hybridized to an MG-U74Av2 array (Affymetrix, Santa Clara, CA) using an Affymetrix fluidics station, and scanned with an Affymetrix scanner, according to the Affymetrix protocols. Data were analyzed using the Affymetrix Microarray Suite (MAS) v.5.0 with all of the parameters set at default values (a global normalization was applied). The probe sets that had 2 or 3 absent A MAS detection calls per group ( 3 samples) in all groups were excluded; therefore, genes that had more than 2 present calls in any one of the groups were included in the analysis). Further, probe sets with signal intensities less than 50 were omitted because preliminary evaluation by RT-PCR revealed poor reproducibility for genes with lower signal intensities. Statistical analyses were performed by Welch's t-test. Affymetrix MAS5.0-normalized signal intensities were submitted to the Gene Expression Omnibus [64] and are available under the series ID: GSE8006.

\section{Real-time RT-PCR}

All mouse primer and probe sets used TaqMan ${ }^{\circledR}$ Gene Expression Assays (Applied Biosystems, Foster City, CA) or Custom TaqMan ${ }^{\circledast}$ Gene Expression Assays (Applied Biosystems). Total RNA was purified from large intestine ( $n=4-6$ per group) as described in the previous paragraph. Reverse transcription was performed with 1 ug of total RNA using TaqMan Reverse Transcription Reagents (Applied Biosystems). Real time-PCR analysis was performed using an ABI Prism 7900HT (Applied Biosystems) with the following thermal cycling conditions: 1 cycle at $55^{\circ} \mathrm{C}$ for $10 \mathrm{~min}$, followed by 40 cycles at $95^{\circ} \mathrm{C}$ for $15 \mathrm{sec}$ and $60^{\circ} \mathrm{C}$ for $1 \mathrm{~min}$. All samples were run in triplicates. Data were normalized by using Irf1, the expression of which had been found to be quite stable among groups in the present experimental setting, as determined by GeneChip and RT-PCR analyses. GADPH and beta-actin fluctuated greatly and slightly, respectively, which is presumably a reflection of the massive changes in tissue organization among microflora -absent and microflora present intestines.

\section{Cloning and sequencing of CRSs}

Fragments of the Defcrs family were amplified using the primers common for the family (forward, 5'-ATGAAGAGACTTGTCCTCCTC-3'; reverse, 5'-CTTCTTGAAGAGCAGAGCCTT-3') from total RNA from the large intestine of GF- and SPF mice by RT-PCR using TaqMan Reverse Transcription Reagents (Applied Biosystems) and Advantage HF2 PCR kit (Clonhech, Mountain View, CA). The fragments were cloned into pT7Blue vector using a pT7Tblue Perfectly Blunt Cloning Kit (Merck, Darmstadt, Germany) according to the manufacture's instructions. The inserts were checked by colony-direct PCR and sequenced using ABI PRISM ${ }^{\circledast} 3100$ Genetic Analyzer (Applied Biosystems). The dendrogram was made from the sequence data by Contig Express and the Align X equipped in the Vector NTI advance Ver.9 (Invitrogen, Carlsbad, CA). BLAST searches on the NCBI database were performed to identify the gene name.

\section{Induction and quantitation of IFN- $\alpha$ protein}

Tilorone analog R11567DA (Sigma, St.Louis, MO) was administered p.o. to IQI SPF mice at a dose of $100 \mathrm{mg} / \mathrm{kg}$ [65]. At 4 and 20 hours later, after cervical dislocation, 
blood samples were collected from the cardiac ventricle. The small and large intestines were then dissected and snap-frozen in liquid nitrogen. The blood was allowed to clot at room temperature for more than 30 minutes and centrifuged to obtain serum samples. The sera and intestines were stored at $-80^{\circ} \mathrm{C}$ until use. At assay, the intestinal samples were thawed, homogenized in PBS buffer with protease inhibitor cocktail Mini (Roche Diagnotics, Basel, Switzerland), and centrifuged at $15000 \mathrm{~g}$ for $5 \mathrm{~min}$ at $4{ }^{\circ} \mathrm{C}$, and the supernatant was saved. The amount of IFN- $\alpha$ protein in the supernatant and serum was assessed using a commercially available IFN- $\alpha$ ELISA kit (PBL Biomedical Laboratories, Piscataway, NJ), which specifically detects the IFN- $\alpha$ s, $\alpha 4, \alpha 5, \alpha 6$ and $\alpha 9$.

\section{In situ hybridization}

The protocol for in situ hybridization has been described previously [66]. Briefly, after acetylation, dehydration, and delipidation pretreatment, mRNAs in sections were hybridized with specific Brigati-Tail oligonucleotide probes using a MicroProbe Staining system (Falma, Tokyo Japan). The sequences of the probes used were Ifna1, 5'TTCAGGGGAAATTCCTGCACCCCCA-3'; Ifit1，5'-TTCGCAAAGCAGGCCATGGC-3'; Irf7， 5'-ATTTTCCGTGGCTGGGCCCACA-3'; Tlr7, 5'TTTCCATGGTCCTGCTGGCCGA-3'; Oaslg, 5'-TTGGTTGGGCGCTGCTTCAGGA-3'. After post hybridization, the biotin-labeled hybrids were sequentially detected with alkaline phosphatase-conjugated streptavidin with stable DAB. Hybridization with antisense oligonucleotide probes for respective mRNAs gave no specific signals (data not shown).

\section{Immunohistochemistry}

Immunohistochemistry was performed on frozen-sections of mid-colon post-fixed by acetone using the following primary antibodies, PE- or FITC-conjugated antiCD11c (rat mAb, M1/70, BD Pharmingen, Franklin Lakes, NJ), PE- or FITC-anti-CD11b (hamster mAb, HL3, BD Pharmingen), PE- or FITC- or APC-anti-mPDCA1 (rat mAb, JF05-1C2.4.1, Miltenyi Biotec, Bergisch Gladbach, Germany), anti-ISG15 (rabbit pAb, AP1150a, Abgent, SanDiego, CA). Sections were incubated overnight at $4^{\circ} \mathrm{C}$ in primary antibodies diluted in antibody diluent (DAKO, Glostrup (Denmark), Secondary antibodies (Alexafluor488-, or Alexafluor-647-labeled anti-rabbit IgGs) and DAPI (Molecular Probe), diluted in antibody diluent, were reacted for $2 \mathrm{~h}$ at room temperature. Sections were viewed by a laser-scanning confocal microscope FV1000 (Olimpus, Tokyo, Japan). In control sections, primary antibodies were omitted and no staining was observed in these sections.

\section{List of abbreviations}

CRS: cryptdin-related sequences; CV: conventional; ex-GF: miroflora-reconstituted mice; GF: germ-free; IECs: intestinal epithelial cells, IFN: interferon; IPC: type 1 interferon producing cells; LI: large intestine; PP: Peyer's patches; SPF: specific pathogen-free.

\section{Authors' contributions}

KM participated in most experiments. MY participated in the design of the study, immunohistochemistry, data analysis and coordination, and drafted the manuscript. NA carried out the anterior half of the experiments of this study. MN and KT participated in RT-PCR. SaI and SeI carried out in situ hybridization. $\mathrm{KH}$ and YO participated in the design and coordination of the microflora reconstitution experiments. AI participated in the design of the study and coordination. KW conceived the study and participated in its design and coordination. All authors read and approved the final manuscript.

\section{References}

I. Backhed F, Ley RE, Sonnenburg JL, Peterson DA, Gordon Jl: Hostbacterial mutualism in the human intestine. Science 2005, 307(5717): 1915-1920.

2. Kelly D, Conway S, Aminov R: Commensal gut bacteria: mechanisms of immune modulation. Trends Immunol 2005, 26(6):326-333.

3. Macpherson AJ, Geuking MB, McCoy KD: Immune responses that adapt the intestinal mucosa to commensal intestinal bacteria. Immunology 2005, I I 5(2): I53- I62.

4. Forchielli ML, Walker WA: The role of gut-associated lymphoid tissues and mucosal defence. Br J Nutr 2005, 93 Suppl I:S4I-8.

5. Macpherson AJ, Harris NL: Interactions between commensal intestinal bacteria and the immune system. Nat Rev Immunol 2004, 4(6):478-485.

6. Little MC, Bell LV, Cliffe LJ, Else KJ: The characterization of intraepithelial lymphocytes, lamina propria leukocytes, and isolated lymphoid follicles in the large intestine of mice infected with the intestinal nematode parasite Trichuris muris. J Immunol 2005, I 75( I 0):6713-6722.

7. Resendiz-Albor AA, Esquivel R, Lopez-Revilla R, Verdin L, MorenoFierros L: Striking phenotypic and functional differences in lamina propria lymphocytes from the large and small intestine of mice. Life Sci 2005, 76(24):2783-2803.

8. Maeda Y, Noda S, Tanaka K, Sawamura S, Aiba Y, Ishikawa H, Hasegawa $\mathrm{H}$, Kawabe $\mathrm{N}$, Miyasaka $M$, Koga $\mathrm{Y}$ : The failure of oral tolerance induction is functionally coupled to the absence of $T$ cells in Peyer's patches under germfree conditions. Immunobiology 200I, 204(4):442-457.

9. Yamanaka T, Helgeland L, Farstad IN, Fukushima H, Midtvedt T, Brandtzaeg P: Microbial colonization drives lymphocyte accumulation and differentiation in the follicle-associated epithelium of Peyer's patches. J Immunol 2003, I 70(2):8I 6-822.

10. Ayabe T, Satchell DP, Pesendorfer P, Tanabe H, Wilson CL, Hagen SJ, Ouellette AJ: Activation of Paneth cell alpha-defensins in mouse small intestine. J Biol Chem 2002, 277(7):5219-28. Epub 200I Dec 3..

II. Bry L, Falk P, Huttner K, Ouellette A, Midtvedt T, Gordon JI: Paneth cell differentiation in the developing intestine of normal and transgenic mice. Proc Natl Acad Sci $U$ S A 1994, 91(22): 10335-10339.

12. Satoh Y, Ishikawa K, Ono K, Vollrath L: Quantitative light microscopic observations on Paneth cells of germ-free and exgerm-free Wistar rats. Digestion I986, 34(2): I I5-I2I.

13. Mysorekar IU, Lorenz RG, Gordon JI: A gnotobiotic transgenic mouse model for studying interactions between small intestinal enterocytes and intraepithelial lymphocytes. J Biol Chem 2002, 277(40):378 I I-9. Epub 2002 Jul 22.. 
14. Keilbaugh SA, Shin ME, Banchereau RF, McVay LD, Boyko N, Artis D, Cebra JJ, Wu GD: Activation of Reglllbeta/gamma and interferon gamma expression in the intestinal tract of SCID mice: an innate response to bacterial colonisation of the gut. Gut 2005, 54(5):623-629.

I5. Rhee SJ, Walker WA, Cherayil BJ: Developmentally regulated intestinal expression of IFN-gamma and its target genes and the age-specific response to enteric Salmonella infection. J Immunol 2005, I75(2): I I27-II36.

16. Tanaka $\mathrm{K}$, Ishikawa $\mathrm{H}$ : Role of intestinal bacterial flora in oral tolerance induction. Histol Histopathol 2004, I 9(3):907-9l4.

17. Matsumoto S, Nanno M, Watanabe N, Miyashita M, Amasaki $H$ Suzuki K, Umesaki Y: Physiological roles of gammadelta T-cel receptor intraepithelial lymphocytes in cytoproliferation and differentiation of mouse intestinal epithelial cells. Immunology 1999, 97(I): 18-25.

18. Rask C, Evertsson S, Telemo E, Wold AE: A full flora, but not monocolonization by Escherichia coli or lactobacilli, supports tolerogenic processing of a fed antigen. Scand J Immunol 2005, $61(6): 529-535$.

19. Prioult G, Fliss I, Pecquet S: Effect of probiotic bacteria on induction and maintenance of oral tolerance to beta-lactoglobulin in gnotobiotic mice. Clin Diagn Lab Immunol 2003, I 0(5):787-792.

20. Hooper LV, Wong MH, Thelin A, Hansson L, Falk PG, Gordon JI: Molecular analysis of commensal host-microbial relationships in the intestine. Science 200I, 29 I(5505):88I-884.

21. Mutch DM, Simmering R, Donnicola D, Fotopoulos G, Holzwarth JA, Williamson G, Corthesy-Theulaz I: Impact of commensal microbiota on murine gastrointestinal tract gene ontologies. Physiol Genomics 2004, I 9(I):22-31. Epub 2004 Jun 29.

22. Kato $\mathrm{H}$ : Animal models derived from the ICR mouse for human diseases. Medical Immunology 1989, I 7:353-6I (in Japanese).

23. Saegusa J, Kiuchi $\mathrm{Y}$, Itoh T: Antinucleolar autoantibody induced in mice by mercuric chloride--strain difference in susceptibility. Jikken Dobutsu 1990, 39(4):597-599.

24. Saegusa J, Yasuda A, Kubota $\mathrm{H}$ : IQI/Jic mice have thymic B cells. Exp Anim 1996, 45(4):353-360.

25. Saegusa J, Kubota $H$ : Sialadenitis in IQI/Jic mice: a new animal model of Sjogren's syndrome. I Vet Med Sci 1997, 59(1 0):897-903.

26. Ikeda M, Kuroki K, Suzuki H, Nakayama H, Saegusa J, Doi K: Picryl chloride-induced allergic dermatitis in IQI/Jic female mice. Exp Toxicol Pathol 2000, 52(3):235-240.

27. Jung JY, Saegusa J, Nakayama H, Doi K: Comparative study on picryl chloride (PCL)-induced contact dermatitis in female IQI/ Jic and BALB/c mice. Exp Anim 2004, 53(2):89-96.

28. Fukushima $\mathrm{K}$, Ogawa $\mathrm{H}$, Takahashi $\mathrm{K}$, Naito $\mathrm{H}$, Funayama $\mathrm{Y}$, Kitayama T, Yonezawa H, Sasaki I: Non-pathogenic bacteria modulate colonic epithelial gene expression in germ-free mice. Scand J Gastroenterol 2003, 38(6):626-634.

29. Hughes $A L$, Nei M: Evolution of the major histocompatibility complex: independent origin of nonclassical class I genes in different groups of mammals. Mol Biol Evol I 989, 6(6):559-579.

30. Wu M, van Kaer L, Itohara S, Tonegawa S: Highly restricted expression of the thymus leukemia antigens on intestinal epithelial cells. J Exp Med I99I, I74(I):213-218

31. Israel A, Kimura A, Fournier A, Fellous M, Kourilsky P: Interferon response sequence potentiates activity of an enhancer in the promoter region of a mouse $\mathbf{H}-2$ gene. Nature 1986, 322(608I):743-746.

32. Raval A, Puri N, Rath PC, Saxena RK: Cytokine regulation of expression of class I MHC antigens. Exp Mol Med 1998, 30(I): $1-13$.

33. Doxsee CL, Riter TR, Reiter MJ, Gibson SJ, Vasilakos JP, KedI RM: The immune response modifier and Toll-like receptor 7 agonist S-27609 selectively induces IL-I 2 and TNF-alpha production in CDI I c+CD I I b+CD8- dendritic cells. J Immunol 2003 I 7 I(3): I I56-I I63.

34. Edwards AD, Diebold SS, Slack EM, Tomizawa $\mathrm{H}$, Hemmi $\mathrm{H}$, Kaisho T, Akira S, Reis e Sousa C: Toll-like receptor expression in murine DC subsets: lack of TLR7 expression by CD8 alpha+ DC correlates with unresponsiveness to imidazoquinolines. Eur J Immunol 2003, 33(4):827-833.
35. Shao L, Kamalu O, Mayer L: Non-classical MHC class I molecules on intestinal epithelial cells: mediators of mucosal crosstalk. Immunol Rev 2005, 206: 160-I76.

36. Snoeck V, Goddeeris B, Cox E: The role of enterocytes in the intestinal barrier function and antigen uptake. Microbes Infect 2005, 7(7-8):997-1004.

37. Hornef MW, Putsep K, Karlsson J, Refai E, Andersson M: Increased diversity of intestinal antimicrobial peptides by covalent dimer formation. Nat Immunol 2004, 5(8):836-43. Epub 2004 Jul 4 ..

38. Huttner KM, Ouellette AJ: A family of defensin-like genes codes for diverse cysteine-rich peptides in mouse Paneth cells. Genomics 1994, 24( I):99-109.

39. Putsep K, Axelsson LG, Boman A, Midtvedt T, Normark S, Boman HG, Andersson M: Germ-free and colonized mice generate the same products from enteric prodefensins. J Biol Chem 2000, 275(5I):40478-40482.

40. Ogawa H, Fukushima K, Sasaki I, Matsuno S: Identification of genes involved in mucosal defense and inflammation associated with normal enteric bacteria. Am J Physiol Gastrointest Liver Physiol 2000, 279(3):G492-9.

41. Cunliffe RN: Alpha-defensins in the gastrointestinal tract. Mol Immunol 2003, 40(7):463-467.

42. Wada R, Yamaguchi T, Tadokoro K: Colonic Paneth cell metaplasia is pre-neoplastic condition of colonic cancer or not? J Carcinog 2005, 4(I):5.

43. Bluyssen HA, Vlietstra RJ, Faber PW, Smit EM, Hagemeijer A, Trapman J: Structure, chromosome localization, and regulation of expression of the interferon-regulated mouse Ifi54/Ifi56 gene family. Genomics 1994, 24(I): | 37-I48.

44. Gilly M, Damore MA, Wall R: A promoter ISRE and dual 5' YY I motifs control IFN-gamma induction of the IRG-47 G-protein gene. Gene 1996, I79(2):237-244

45. Carlow DA, Teh SI, Teh HS: Specific antiviral activity demonstrated by TGTP, a member of a new family of interferoninduced GTPases. J Immunol I998, I 6 I (5):2348-2355.

46. Olszewski MA, Gray J, Vestal DJ: In silico genomic analysis of the human and murine guanylate-binding protein (GBP) gene clusters. J Interferon Cytokine Res 2006, 26(5):328-352.

47. Sorace JM, Johnson RJ, Howard DL, Drysdale BE: Identification of an endotoxin and IFN-inducible cDNA: possible identification of a novel protein family. J Leukoc Biol I995, 58(4):477-484

48. Leaman DW, Chawla-Sarkar M, Jacobs B, Vyas K, Sun Y, Ozdemir A, Yi T, Williams BR, Borden EC: Novel growth and death related interferon-stimulated genes (ISGs) in melanoma: greater potency of IFN-beta compared with IFN-alpha2. J Interferon Cytokine Res 2003, 23( I 2):745-756

49. Chin KC, Cresswell P: Viperin (cig5), an IFN-inducible antiviral protein directly induced by human cytomegalovirus. Proc Natl Acad Sci U S A 200I, 98(26): I5I25-I5I30.

50. Honda K, Yanai H, Takaoka A, Taniguchi T: Regulation of the type I IFN induction: a current view. Int Immunol 2005, I 7(I I):|367-78. Epub 2005 Oct 7.

5I. Taniguchi T, Takaoka A: A weak signal for strong responses: interferon-alpha/beta revisited. Nat Rev Mol Cell Biol 200I, 2(5):378-386.

52. Nussbaum JM, Major M, Gunnery S: Transcriptional upregulation of interferon-induced protein kinase, $\mathbf{P K R}$, in breast cancer. Cancer Lett 2003, I 96(2):207-2I6.

53. Wathelet MG, Berr PM, Huez GA: Regulation of gene expression by cytokines and virus in human cells lacking the type-I interferon locus. Eur J Biochem 1992, 206(3):901-910.

54. de Veer MJ, Holko M, Frevel M, Walker E, Der S, Paranjape JM, Silverman $\mathrm{RH}$, Williams BR: Functional classification of interferonstimulated genes identified using microarrays. J Leukoc Biol 200I, 69(6):912-920.

55. Nakaya T, Sato M, Hata N, Asagiri M, Suemori H, Noguchi S, Tanaka $\mathrm{N}$, Taniguchi $\mathrm{T}$ : Gene induction pathways mediated by distinct IRFs during viral infection. Biochem Biophys Res Commun 200I, 283(5): I I50- I I56.

56. Liu Y): IPC: professional type I interferon-producing cells and plasmacytoid dendritic cell precursors. Annu Rev Immunol 2005, 23:275-306

57. Sen GC, Sarkar SN: The interferon-stimulated genes: targets of direct signaling by interferons, double-stranded RNA, and viruses. Curr Top Microbiol Immunol 2007, 3 I 6:233-250. 
58. Sung SS, Fu SM, Rose CE Jr., Gaskin F, Ju ST, Beaty SR: A major lung CDI03 (alphaE)-beta7 integrin-positive epithelial dendritic cell population expressing Langerin and tight junction proteins. J Immunol 2006, I 76(4):2I6I-2I 72.

59. Xu H, Dawson R, Forrester JV, Liversidge J: Identification of novel dendritic cell populations in normal mouse retina. Invest $O p h-$ thalmol Vis Sci 2007, 48(4): I70I-I7I0.

60. Karlis J, Penttila I, Tran TB, Jones B, Nobbs S, Zola H, Flesch IE: Characterization of colonic and mesenteric lymph node dendritic cell subpopulations in a murine adoptive transfer model of inflammatory bowel disease. Inflamm Bowel Dis 2004, I 0(6):834-847.

61. Chowdhury SR, King DE, Willing BP, Band MR, Beever JE, Lane AB, Loor JJ, Marini JC, Rund LA, Schook LB, Van Kessel AG, Gaskins HR: Transcriptome profiling of the small intestinal epithelium in germfree versus conventional piglets. BMC Genomics 2007, $8(1): 215$.

62. Fukushima K, Sasaki I, Ogawa H, Naito H, Funayama Y, Matsuno S: Colonization of microflora in mice: mucosal defense against luminal bacteria. J Gastroenterol I999, 34(I):54-60.

63. Hill RR, Cowley HM: Effects of bacterial colonization on mucosal structure of the large bowel of neonatal rats. Acta Anat (Basel) 1988, 132(3):230-233.

64. GEO: [http://www.ncbi.nlm.nih.gov/projects/geo/].

65. Stringfellow DA: Interferon inducers: theory and experimental application. In Interferon and Interferon Inducers Edited by: Stringfellow DA. New York, Marcel Dekker, Inc.; 1980: 145-166.

66. Tsuchiya B, Sato Y, Montone KT, Nagai T, Kameya T: Four-hour double staining for in situ hybridization and immunohistochemistry. Journal of Histotechnology 2000, 23(4):32I-325.

Publish with Bio Med Central and every scientist can read your work free of charge

"BioMed Central will be the most significant development for disseminating the results of biomedical research in our lifetime. "

Sir Paul Nurse, Cancer Research UK

Your research papers will be:

- available free of charge to the entire biomedical community

- peer reviewed and published immediately upon acceptance

- cited in PubMed and archived on PubMed Central

- yours - you keep the copyright

Submit your manuscript here:

http://www.biomedcentral.com/info/publishing_adv.asp
BiolMedcentral 